УДК 658

DOI: https://doi.org/10.32782/2413-9971/2019-27-1

\author{
Matthnai Ekouaghe \\ Postgraduate Student, Assistant Lecturer, \\ Department of Tourism, Faculty of International Economic Relations \\ Simon Kuznets Kharkiv National University of Economics
}

\author{
Маттхнаі Екоуагхе \\ аспірант, асистент кафедри туризму, \\ факультет міжнародних економічних відносин, \\ Харківський національний економічний університет \\ імені Семена Кузнеия
}

\title{
FORMATION OF A MANAGEMENT SYSTEM FOR A TOURISM ENTERPRISE BASED ON THE USE OF INNOVATIVE MARKETING TECHNOLOGIES
}

Summary. This article deals with the formation of a management system for a tourism enterprise based on the use of innovative marketing technologies. Development and decision making in tourism marketing are accompanied by the use of techniques that take into account the conditions of uncertainty in business and the degree of risk. The latter can be significantly reduced by having reliable, sufficient, real, and timely information. The concept of marketing assumes that information is not a less important resource of the enterprise than finance and personnel. Thus, to ensure the successful operation of a tourist enterprise at all stages of its activity, marketing information is of paramount importance. Explanatory information makes it possible to formulate an idea of the factors and causes of a change in the management system. This makes that planned information is used in the development and decision-making process for goals, strategies and indeed marketing programs. The purpose of the article is to study the factors of influence of marketing on the management system of a company, as well as the vectors which may lead to the design of an enterprise's administrative structure using marketing technologies.

Key words: information, management, marketing strategy, information communication technologies, marketing technologies.

Introduction and brief literature review. In a tourism business, a good manager should be a measure of evaluating the strengths and weaknesses of his business but taking the appropriate operating, organizational, tactical, strategic measures.

For this, it relies on economic, social, accounting, and financial information. In the modern information society, the importance of information as a commodity rises. This is a consequence of the general growth of information needs and an expression of the development of the information services industry. Evidence of this is the increased contribution of the information sector to the creation of national wealth. The successful operation of the enterprise is impossible without obtaining reliable information about the current situation in the market. There are a number of firms whose activity is to sell information to interested companies. The most popular enterprises in today's market include tourism industry enterprises. In the process of managing this type of activity, businesses can talk about information as a subject of commercial distribution. following this state of affairs, different management models can be put in place by companies. Conceptual models of D. Ratmela, P. Eiglier and E. Langeard, C. Grenros, P. Kotler, J. McCarthy, M. Bitner and other scientists made a definite contribution to the methodology of marketing services. Organizational and managerial methods provide support to the organization in work and high labour discipline, without which it is practically impossible to effectively manage the economy. Such tasks could be eased by the implementation of information communication technologies such as marketing technologies.

Research results. The management of a tourism company is much the same as the management of any other enterprise but it has its own characteristics.

They are related to the multivariate tourism activities, the uncertainty of the final result, often dependent on partners (carriers, hoteliers, etc.), the rapid variability of external factors, the need to work with consumers of services not only at the time of sale but also in the process of their implementation.
In recent decades, various spheres of the tourist business have been successfully developing on the basis of strategic management.

Strategic management as a concept of travel agency management allows us to consider the organization as a whole, and also to explain from a system-wide perspective, why some travel agencies are developing successfully while others are in a state of stagnation.

Strategic management is the process of making and implementing decisions based on strategic planning that compares the resource potential of a travel agency with the capabilities and threats of the external environment.

There are many definitions of strategy but they all imply a well-thought-out set of norms and rules underlying the development and adoption of strategic decisions that affect the future state of an enterprise.

A strategy is a general program of action that identifies problem priorities and resources to achieve the main goal. The strategy formulates the main ways to achieve the goal in such a way that the company receives a single direction of movement.

Strategic planning methods have not yet found wide application in the activities of travel agencies. Meanwhile, such planning allows taking into account the needs and specifics of the tourist market, and therefore, optimizing current activities and foreseeing possible complications in the development of business processes. Strategic management of a travel agency is a sequence of actions from the formulation of a common goal to the analysis of results and the adjustment of tasks (Fig. 1). As we can see in Figure 1, the process of strategic planning of travel agency activities includes six interrelated stages:

1) study of the external and internal environment of the travel agency;

2) determining the main areas of work;

3) comparison of the results of the first and second stages;

4) identification of possible options for strategies; 


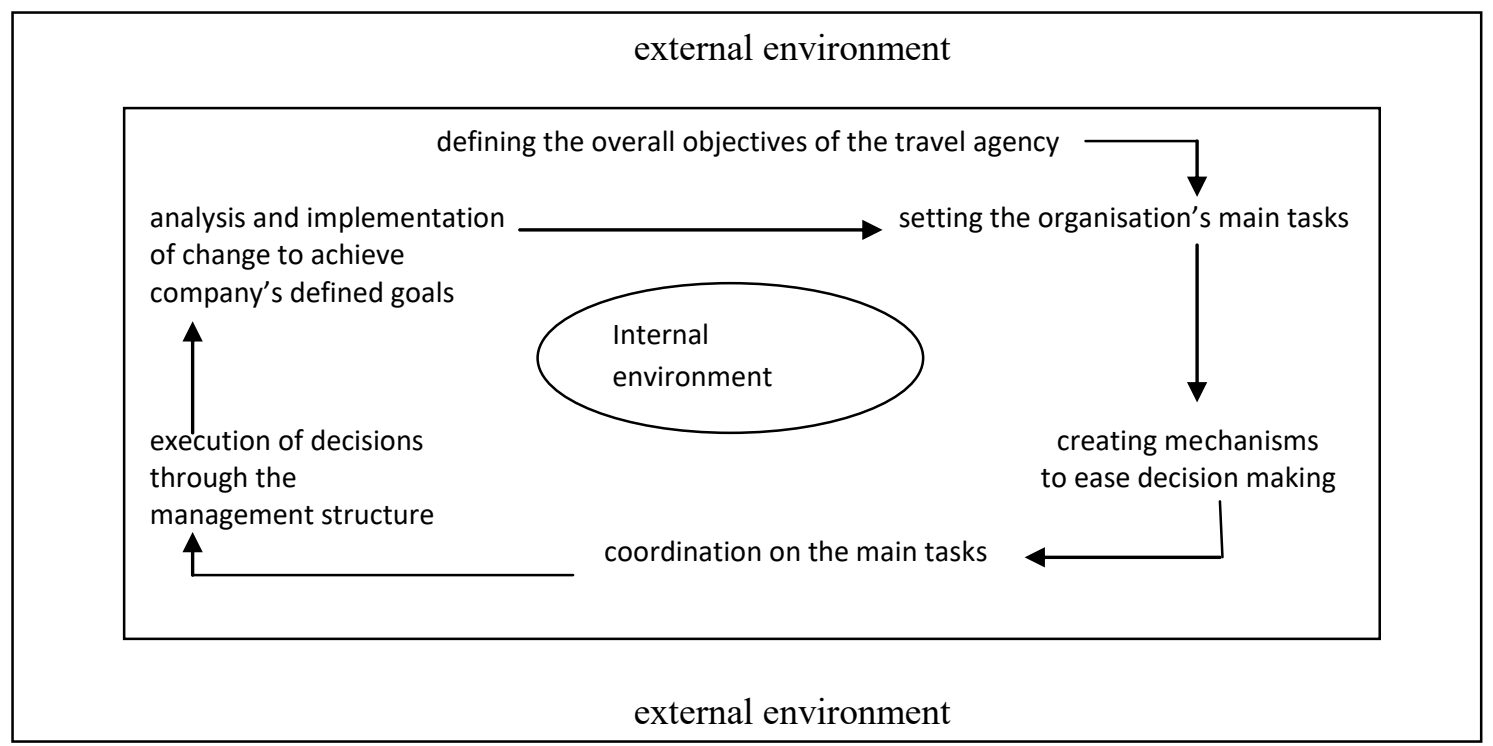

Fig. 1. The main cycle of the strategic management of the travel agency

5) the choice of one of the options and the formulation of its own strategy;

6) preparation of a strategic plan based on the development carried out.

Analysis of the travel agency environment is the process of identifying the most important elements of the external and internal environment that may affect the ability to achieve goals. The external environment of a travel agency is a combination of factors affecting its strategic development. These include political, socio-cultural, economic, technological, legal, and other factors.

In relation to the external environment of the tourist company, there are two types of control systems. The first type is associated with the definition of positions (long-term and strategic planning), i.e. we are talking about the entry of the travel agency in its environment.

The second type of control is associated with a timely response (control by strong signals, weak signals, under unexpected conditions) in response to rapid and unexpected changes in the environment of the travel agency.

The internal environment of the travel agency includes such elements as the production of tourist products, finance, marketing, personnel management, organizational structure, etc.

The analysis of the internal environment gives an idea of the strengths and weaknesses of the travel agency, its internal capabilities.

Though tourism businesses are multiple. They operate in one or more sub-sectors of tourism related to the different components of the tourism product (accommodation, transport, animation ...).

Companies in this sector naturally welcome tourist customers (holidaymakers, conventioneers), but also non-tourism customers (for example, businessmen on business trips).

The purpose of tourism companies is to inform, advise, assist, and accommodate the tourist in the preparation and conduct of their trip and their stay. These different activities explain a large number of businesses in the tourism sector.

Unlike distributors in many industries, travel agencies do not deal with physical products but with information.

With the internalization of markets, the tourist company must adapt, if possible, anticipate, sometimes influence, in any case react with agility.
For conditions to be good, business managers need the right information at the right time for decision-making. The central place to occupy information in the decision-making process is well established.

This idea of the preponderance of information was emphasized more than forty years ago by Lemoigne (1973, 1974) to the point that it draws attention to the confusion often made between information and the decision. According to the author, information and decision are related but not confused. In favour of advances in information technology (software, databases), companies can now collect, process, store, and disseminate large volumes of information, and all these operations are carried out more and more quickly and at a reasonable cost. But, if the information is no longer, as in the past, a scarce resource. It is its organization in a decisionmaking database that allows the analysis and exploitation for decision-making purposes. In common usage, the terms "data" and "information" are often considered synonymous. However, when seeking precision, it appears that the data becomes information only when it is received by a human being who interprets it. Information is data observed by an actor. Observation involves comparison to other data for interpretation. To pass from the rank of data to that of information supposes that the knowledge of the data contributes to the action of the one who observes it. Data (words, numbers, images, sounds, etc.) is, therefore, the raw material of information through a process of interpretation that gives them meaning and meaning. There is really no single definition of the information concept. The definitions vary according to the standards (Haouet, 2008). Among the many definitions proposed, we can retain the one elaborated by Davis, Olson, Ajenstat and Peaucelle (1986), which refers to the functions of information, regardless of its form and its treatment: information is an image of objects and facts. It represents them, corrects or confirms the idea we had. The information contains a surprising value, in that it brings a knowledge that the recipient did not have or could not predict. This definition recognizes that information, as an element of knowledge, reduces uncertainty by modifying the probabilities assigned to possible states of the future.

For March (1991), the main uncertainty in decision-making is the ignorance of information held by others and their likely actions. 
The main reason for being information is its role in the process of reducing this uncertainty. Information is also valuable because it allows you to choose, make decisions, and act. Its value is thus linked to its use in the context of decision-making. Thus, information gives meaning to a decisionmaking situation and thus modifies both the structure of the options and the preferences sought.

The information remains at the heart of the management system of the company, as it is central to any decision to be made. Being well informed is often (almost always) a condition for success. Many questions revolve around this notion: where and how to get informed? What information does it need? At what cost can it be obtained? What are its different channels of communication, circulation? What to do in case of over-information?

Information is information. Information worthy of the name improves the degree of knowledge of the phenomenon studied and makes it possible to make effective decisions. In regards to that, managers of tourism development and promotion in their region, Destination Management Organizations (DMOs) are pillars of the tourism industry. A number of challenges await them as they often have to consider new avenues of funding, embrace new technologies, face more competition, and adapt to the changing needs of consumers.

The first generation of DMOs was limited to the status of a public body funded entirely by the state. Although this type of structure still predominates, several new forms have emerged, from national, regional, and municipal organizations. The following table, from a 2004 World Tourism Organization (UNWTO) survey, summarizes the situation in the world. Canada, through the Canadian Tourism Commission, adopts the model of a public-private partnership, as are the United Kingdom, France, Denmark and Australia. Countries such as Germany, Italy, Greece and Portugal favour a totally public structure. Some destinations choose to go against the tide, seeing the intervention of the state useless and preferring to rely on the natural forces of the market. This is observed in the United States, the Netherlands, and Japan. The latter simply opted for the privatization of its national tourism office. In the highly evolving world of tourism, DMOs have no choice but to follow the parade and adapt as well. The main difficulty according to Arthur Oberascher, CEO of the Austrian National Tourist Board, comes from the fact that they are primarily supply-oriented in order to meet the interests of the member companies of the destination.

The challenge is to better understand the demand to adapt to customer needs. DMOs are expected to play a greater role as knowledge managers, acting as information brokers between customers and suppliers.

Ultimately, the leaders of the DMOs should be able to count, like the hotel managers, on daily activity reports: inventories, customer profiles and expenses, financial analysis, etc. The establishment of a 24-hour communication network with destination providers should be the norm. Obviously, we are not there, but it gives an indication of the direction the tourism industry is heading.

In addition, the increasing trend of consumers using the Internet to search for information on tourist destinations and to purchase their trip is one of the major changes in the operational environment of DMOs.

These must now take into account this new attitude of the customer and adapt to the digital age of information. According to UNWTO, the majority of national organizations have an e-commerce strategy, compared to regional or local entities, which do not have any (at least in half).

Considering these facts, the formation of a management strategy based on digital management tools should be explored, within this framework marketing technologies can constitute a good lead. Labour in tourism management is specific and differs significantly from the activities of workers in other industries, although at first glance it can be assumed that the management of the tourist region and tourist organization relies on the same basis as the management of any enterprise of the "person-person" system. The first feature of tourism lies in the great depth of its penetration and the complexity of the interrelations between its constituting elements.

In the conditions of socio-economic transformation in Ukraine, a tourism enterprise should quickly and adequately reform its management structure and its functions. In the modern information society, the importance of information as a commodity rises. This is a consequence of the general growth of information needs and an expression of the development of the information services industry. Evidence of this is the increased contribution of the information sector to the creation of national wealth. The successful operation of the enterprise is impossible without obtaining reliable information about the current situation in the market. There are a number of firms whose activity is to sell information to interested companies. The most popular enterprises in today's market include tourism industry enterprises. In the process of managing this type of activity, you can talk about information as a subject of commercial distribution. The concept of information as a product implicitly fixes a fundamental requirement for a tourism organization: the success of the commercial dissemination of information as a product is determined primarily by the extent to which the data offered to consumers (tourists) will provide information for them. If the data acts as a commodity, the user deals with information products - data sets formed by their manufacturers for further distribution. The structure of the information product, or the form of data presentation in it, in turn, embodies a certain information system of its manufacturer, which by definition is different from the user's information system.

Of course, travel companies are trying to take into account also consumer systems in their systems. Nevertheless, the information systems of those and others can never fully coincide, because:

a) consumers often do not make out (explicitly or implicitly) their rather vague ideas about what information they need into clear information models, which prevents them from being included in the product concept;

b) even if such models somehow exist, then, firstly, the manufacturer may not know about them and/or misinterpret them and, secondly, these models may not coincide with each other, making thereby the construction of an abstract information system "user in general" difficult to solve, and often not a practical task.

Discrepancies of information systems of manufacturers and users are manifested mainly in the fact that the user needs data in a different volume and in a different structure compared to how it is done in the information product. This reduces the efficiency of finding the necessary information because the user must make certain efforts to extract data from information products and to reduce them into a single information array suitable for answering the questions posed. We can assume that the content of each specific information is determined by the needs of users and certain requirements are imposed on the information, such as:

- brevity, clarity of language, timeliness of receipt;

- meeting the needs of specific managers;

- accuracy and reliability, correct selection of primary information, optimal systematization and continuity of the collection and processing of information.

However, the management system is a combination of technical and organizational methods and measures intended 
for solving managerial tasks. It follows that in the market conditions, the information system is also one of the most important elements not only in the selection of a tourist product but also in the management of the commercial activity of a tourist enterprise.

Information support from the point of view of managing the commercial activity of an enterprise is a completely new matter, and therefore, its purposeful development is required. This goal is achievable with the use of marketing technologies, which have a huge array of elements connected to the management of the enterprise. In fact, to identify the specific features of the market activity of tourist enterprises that determine the requirements for information resources in this area, it is necessary to analyse the theoretical approaches to marketing in the service sector since the activity in the field of tourism is characterized by a number of specific features that are also characteristic of the service sector as a whole. According to Henry Assael, services as goods purchased by consumers, but without transferring ownership of them, have the following features:

- the service is non-material and, therefore, intangible, non-conserved, cannot be produced for future use, cannot be packaged, stored or transported; however, the results of the service can be materialized and evaluated;

- the service has the property of inseparability - the provision of the service is inseparable from the seller and the consumer, implies their personal communication; services are most often sold first (payment for treatment, rest, excursions, etc.), and then simultaneously produced and consumed;

- usually, the service is provided to enterprises for a very specific consumer, therefore, each service is unique and has the property of heterogeneity in quality.

Based on their analysis, it is possible to identify the main components of the resource support of marketing activities, reflecting the essence of the specifics of tourist services, as well as corresponding to the rate of informatization of market processes in the service sector:

- the ambivalence of marketing activities in the field of tourist services, combining technology and the art of market activity;

- close cooperation between the producer and the consumer, arising in the process of promoting and providing tourist services;

- intensive information exchange of market participants in the field of tourism;

- the prevailing value of the marketing mix, consisting of seven variables: product, price, promotion, incentives, personnel, process, and material evidence.
Modern information technology is changing the way businesses do business in most consumer service businesses. The enterprises of the tourism industry are also activating the processes of using computer and telecommunications equipment, creating electronic service systems, and using the Internet, which form a powerful resource base for information support of market activities in this market. One of the main elements of information support in making marketing decisions in the activities of tourist enterprises is the marketing information system (marketing technologies).

The role of marketing technologies in the system of marketing management is to determine the information needs for marketing management, its receipt and timely delivery to managers for decision-making. Marketing management is aimed at solving the problem of influencing the level, time frame, and structure of demand for tourist services in order to achieve the company's strategic goals. It is obvious that the development and implementation of marketing technologies elements in the practical activities of tourism enterprises will provide a powerful resource base for quick access to information about the situation on the tourism market, quality superiority over competitors, access to target consumers and the possibility of feedback from them.

Marketing activities of industrial enterprises producing commodity products and enterprises of the service sector have common approaches, however, there are certain differences. Manufacturing enterprises need to establish close ties, mainly with wholesalers and intermediary structures through which they reach consumers. Service enterprises enter into direct contact with their target customers.

As shown in Figure 2, the implementation of the marketing technologies of the tourist enterprise should take into account these differences and be carried out according to the six proposed methodological principles:

1) The principle of the need for the tourist enterprise to fully meet the needs of the target market, which is due to the inseparability of the enterprise-producer of tourism services and the end-user in the process of its provision (business to customer relationship);

2) The principle of accuracy of the used marketing information, according to which the marketing technologies use only reliable external and internal information necessary and sufficient for the tourist enterprise to make adequate management decisions (customer experience and content management);

3) The principle of complexity, in which the marketing technology should ensure the activities of the enterprise, taking into account all the variables of the marketing mix. The

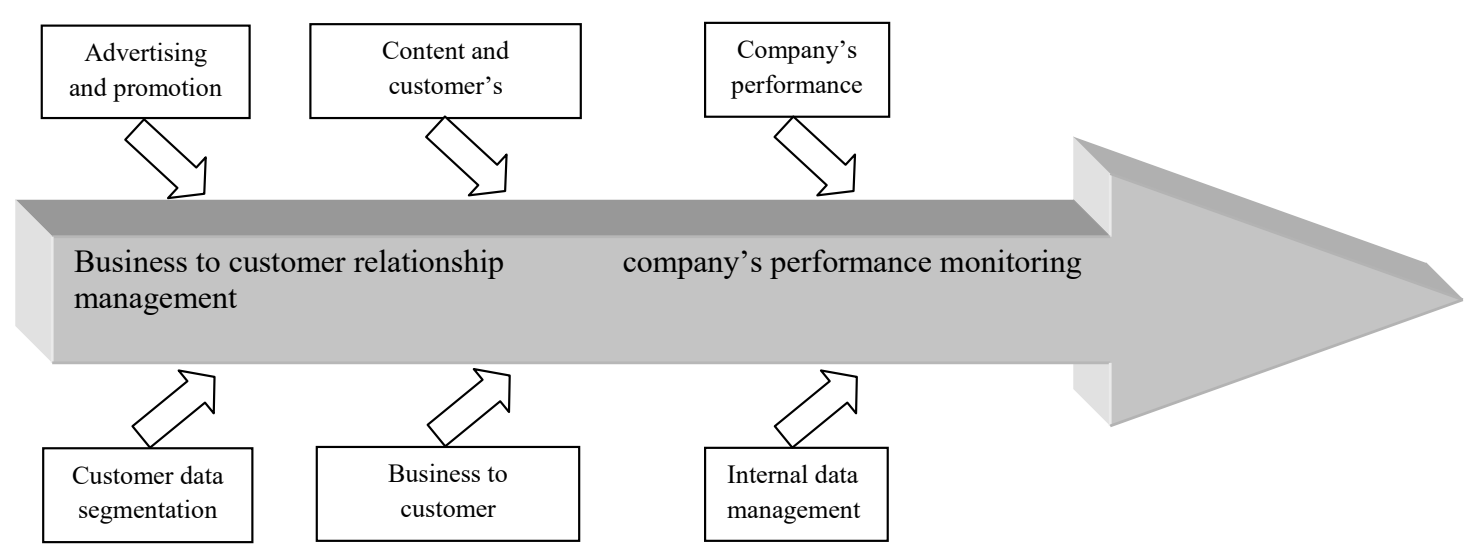

Fig. 2. Conceptual features on which the management system using marketing technologies should be built 
importance of this principle is particularly increasing in enterprises of the sphere of tourism services since, as was shown above, the marketing mix of such enterprises includes more variables than the marketing mix of enterprises producing marketable products (advertising and promotion).

4) The principle of consistency, in accordance with which the marketing technologies should operate in conjunction with other information systems of the tourist enterprise at all stages of the marketing management cycle (internal data management)

5) The principle of continuous improvement of marketing activities, in accordance with which the marketing management in tourism is based on the use of modern scientific and methodological developments and software products that allow businesses to process and store large amounts of marketing data (customer data segmentation).

6) The principle of the process approach, in accordance with which the marketing activities of a tourism enterprise in the framework of an IIA are presented as a set of interrelated and interacting processes, including the processes of planning the market and production activities of an enterprise and analysing the effectiveness of its functioning (company's performance monitoring). As seen here, information sharing can become a vehicle for organizational development. Web-based information and communication technologies (ICTs) offer new opportunities for collaboration and foster the emergence of collective intelligence.

Web 1.0 allowed the diffusion of one-way information without the possibility of interactivity. Web 2.0 puts the user at the heart of information. The user becomes a contributor and beneficiary. Thus, the Web becomes a social, collaborative, community. Web 2.0 opens up a new area, that of collaboration and collective intelligence.

The organization is a privileged place for sharing information and collaborative work. Interactions are numerous and varied, both among the members of the organization and in the relations that the organization has with its external environment. ICTs have revolutionized practices; we can see that with the concept of interoperability.

Interoperability is the property that allows for the unrestricted sharing of resources between different systems.

In short, it is about exploiting the behavioural data of a contact to deduce its appetites and send the right message at the right time by the right channel.

Attention should be paid to choosing the right time to communicate with a contact. It is determined by the behaviour of each individual.

This axis of customization that is time is often set aside by companies that continue to schedule their marketing campaigns on a fixed date. Choosing the right time is a factor for improving However, to achieve this promise, a marketing automation solution must continuously collect behavioural data within the company's information systems. These new tools make it possible to maximize the creativity and efficiency of a working group, even if the individuals are geographically dispersed. The comfort of use, speed of interactions, quality of exchanges: in the long term, the sharing of information in internal helps maximize business ROI. Concentrating customer knowledge in the same place not only improves the profitability of tourism businesses but also capitalizes on the customer's experience.

In the case of the tourism industry, we can say that it is indeed one of the sectors that has been most strongly impacted by the evolution of tools, uses, and digital content. The collection and exploitation of behavioural data are becoming a major challenge for marketing teams looking to improve their performance and adapt to the growing number of communi- cation channels. The multiplicity of channels leads to a dispersion of customer knowledge in systems that, if they are partitioned, ultimately lead to a loss of customer knowledge. This is a recurring problem for companies that consult us. In this context, simultaneously combining the behavioural data exploitation strategy with the cross-channel approach allows us not only to reconstruct the customer's knowledge but also to enrich it with appetence or interest information earlier in the purchasing cycle.

Before the purchase decision is made. Technology solutions, such as marketing technologies, offer the opportunity to exploit this behavioural data and increase customer conversion in a cross-channel and not just digital approach. Marketing technologies were designed to manage the implementation of behavioural and cross-channel relational strategies by centralizing data (customers, prospects and users) in a single marketing datamart. To stay competitive, tourism players must adopt a proactive attitude towards digital.

They must interest, satisfy, give the desire to the tourists to promote their destination: it will be here to devolve an alchemy between the tourist company and the customer, it is here one of the advantages of the digital which invites to the travel, makes the visit attractive, and simplifies the life of the tourist giving a field of possibilities very wide.

Taking into account the aforementioned facts, the management system of the tourism company should function with interactive elements, in which tourism product content management, business to customer relationship oversight, should be at the core of the activity of the said enterprise. As we can see in Figure 3, this system will include six elements:

Content marketing platforms, which helps marketers create quality content, target customers, and manage their contact lists efficiently.

It has a full-funnel marketing system, which helps marketers build, administer, and distribute emails with the help of their marketing tools and applications. Content marketing covers a broad spectrum but it's a strategic marketing approach focused on creating and distributing valuable, relevant, and consistent content to attract and retain a clearly-defined target audience. Ultimately, enhance awareness, encourage loyalty, and increase profitability.

The content management system is an application that is used to manage web content, allowing multiple contributors to create, edit, and publish.

Content in a CMS is typically stored in a database and displayed in a presentation layer based on a set of templates. One major advantage of a CMS is its collaborative nature. Multiple users can log on and contribute, schedule or edit content to be published. Because the interface is usually browser-based, a CMS can be accessed from anywhere by any number of users. When a company uses a CMS to publish its pages, it reduces its reliance on front-end engineers to make changes to the website, making it quicker and easier to publish new content. This may be useful for small and medium enterprises.

Social media management, which is a growing trend among businesses because it can improve results drastically. That's because the tools that businesses can use to manage their social networking give them a great deal of information that can help them gain more followers, become more relevant to the followers that tourism companies may have, and ultimately, grow their business through social media. Social media management not only helps tourism professionals with managing their social network, both outgoing and incoming communications, but also all of the other aspects of small business social marketing more efficiently. It allows them to have a smooth and a working plan as to how they are going to post, respond to followers and fans, and take the information 


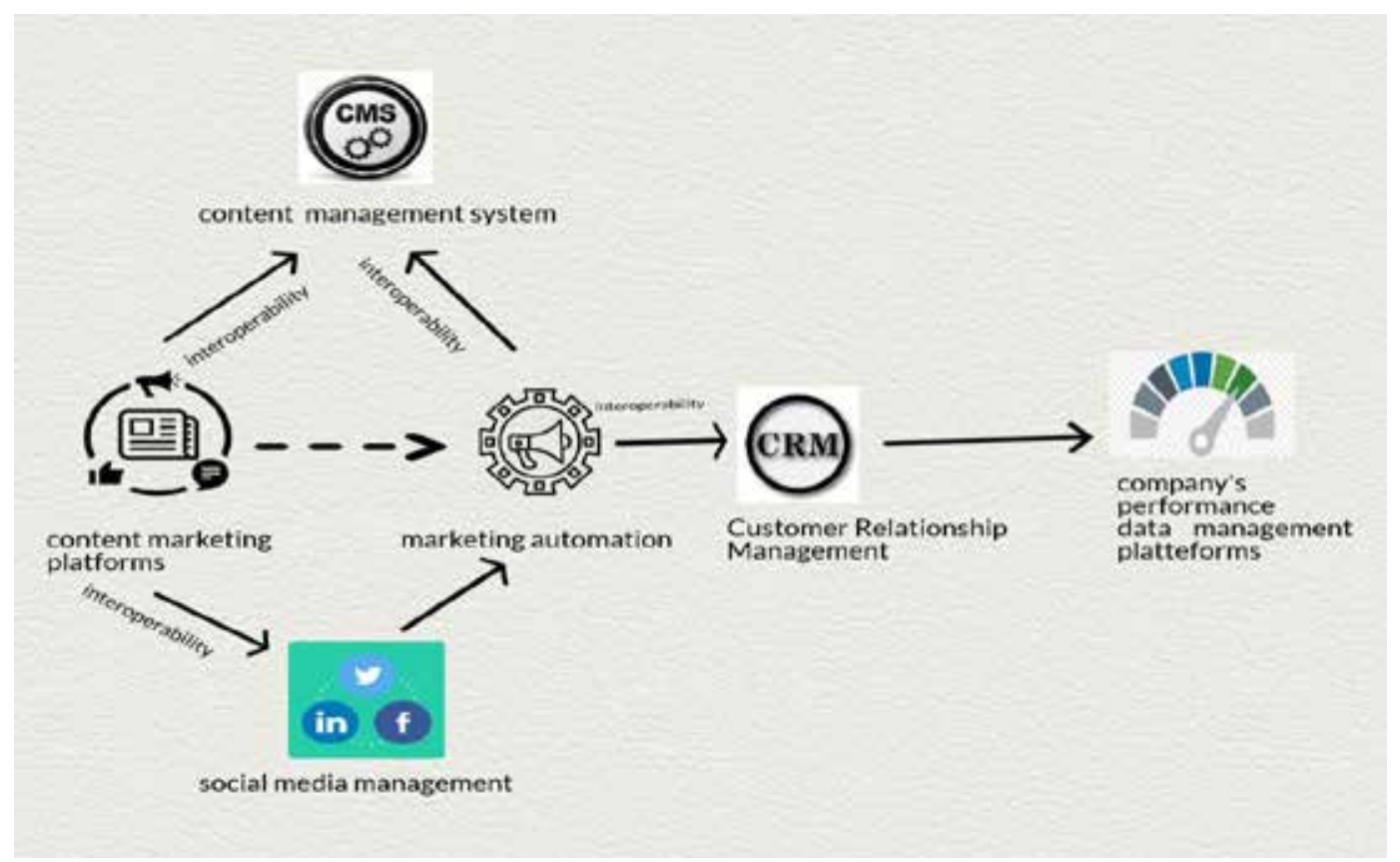

Fig. 3. Proposed management system for a tourism enterprise based on the use of innovative marketing technologies

that they interactions provide so that they can use it to make their business better.

Marketing automation, which is a set of a software system that helps businesses to automate the manual repetitive tasks. This helps to save time, save money on resources, and enables you to focus on more important tasks like planning $\&$ strategy. Automation is based on collected data that analysis behaviour, interests, and trends. Marketing automation is the use of software to automate marketing processes such as customer segmentation, customer data integration, and campaign management. The use of marketing automation makes processes that would have otherwise been performed manually much more efficient and makes new processes possible. Marketing automation is an integral component of customer relationship management.

Customer relationship management, in which all customer data including customer name, previous bookings, address, financial information, and characteristics will be stored in one location and can be accessed from any point This information will allow tourism companies or hotels to understand customer history and provide them with the services they prefer. This effective targeting will allow companies to provide personalized services. automated channel tracking will also allow you to ascertain which mediums are being used in order to make bookings to adjust your future efforts at marketing. The importance of CRM cannot be denied and without proper implementation, there is no way that businesses can work effectively towards attracting and retaining customers. CRM has a direct effect on the returns generated for the business. This is especially true when it comes to delivering personalized care in the service industry, specifically tourism. In an effort to retain customers and expand business operations, businesses have been implementing CRM solutions

Company's management platforms, which are applications or set of programs that help businesses support, improve, and automate their processes. Such software assists in eliminating errors, completing business tasks, reporting activities and increases overall efficiency and effectiveness. This makes it possible to centralize data on the company's performance in real time, which is a powerful development lever for tourism companies. This ensures better communication internally but above all greatly improves the customer experience. All the services of this company have an ideal vision of the progress of the projects executed within the company.

We can see here that such a system gives an opportunity to tour companies to have control over their management strategies in seasonal activities. In a context of crisis, the "physical" actors of tourism suffer from the disintermediation made possible by the rise of the Internet. All these professionals, public or private, must therefore integrate the need to present their offer on the Internet either through their website intern or by referencing through an intermediary. Hotels have understood the importance for tourists to be connected and according to a study conducted by the HRS hotel chain across Europe, we see that $67 \%$ of hotels offer free Wi-Fi to their customers. This investment in the e-tourism sector is the consequence of different issues: a challenge of image (willingness to show a modern and dynamic image), a direct and complementary sales channel (internet is a complementary distribution channel especially for last-minute sales) and a customer loyalty and support tool. The digital challenges for local information and promotion bodies are the same. Whatever their size, location or status, the territorial organizations are concerned in their mission of reception and information by the digital revolution. That is why these new tools are deployed in the offices of tourist offices by integrating digital information services internally but also externally via digital sites or applications. Nonetheless, a more practical view of the aforementioned facts should come into play. Any tourist operator will need specific aspects of the proposed management system. While data is an increasingly important competitive advantage in the digital economy, most organizations continue to treat it differently than other resources, which can lead to poor data quality or silos of information.

Conclusions. The successful work of enterprises in the tourist market is impossible without effective marketing activities. This is associated with the need to develop and implement a whole range of activities, in which the work of all departments of tourist enterprises is aimed at optimizing 
the processes of interaction between consumers and producers of tourist services. At the present stage of development of information and communication technologies, such activities are impossible without developing information resources to ensure the marketing activities of tourist enterprises. Usually, control over the work of the travel company is carried out with the help of the accounting department of the company, which receives all the information about the movement and availability of funds and the implementation of various business operations. The development of the tourist product, advertising and marketing strategy are carried out by the marketing department. In the tourism business, it is necessary to pay maximum attention to studying the problems of supply and demand in the markets. When rendering its services, a travel company should be guided by the problems of tourists and their needs. The solution to such problems is carried out by interviewing potential customers. Quite a significant amount of information is obtained by analysing various advertising brochures and leaflets that are produced by various foreign and Ukrainian firms and their competitors, which again are costly both in time and means.
Treating tourism and content marketing is a major issue for all tourism professionals. Internet visibility has become the heart of their marketing process in this sector. The need to exist outside of all booking intermediaries seems essential today. The ability for hotels, holiday villages, and campsites to generate their own customer traffic is becoming a fundamental criterion of economic independence. This is why marketing technologies become the spearhead of a corporate marketing strategy. Therefore, tourism professionals will have to choose closely the tools of the marketing technologies they may need in the accomplishment of their activities. Big data continues to grow and marketing departments increasingly see the benefits of these technologies for their internal processes, with issues and goals specific to their business. The main objectives related to big data projects led by companies are to improve the services rendered and the customer relationship. Analytics is at the heart of customer data exploitation issues with a particular focus on predictive analysis and unstructured data analysis. This may require a huge array of evaluation methods of the said technologies in the management process of tourist enterprises.

References:

1. Bezrutchenko, Yu.V. Marketing in the socio-cultural service and tourism [Text] / Yu.V. Bezrutchenko. - M.: Dashkov and K, 2010. - 231, [1] p.

2. Bulganina S.V., Tomay D.A. The use of marketing research methods by the company. In the collection: Current Issues of Education and Science. Collection of scientific papers based on the materials of the International Scientific and Practical Conference: in 11 parts. 2014. pp. 32-33.

3. Methods of marketing research in tourism [Electronic resource] // URL: http://edu.dvgups.ru/METDOC/CGU/SOTS_KULT SERVIS/MET_N_ISL/METOD/U_P/frame/4.htm (appeal date: 04.21.2015).

4. Sokolova, MI, Krylova G.D. Marketing: a textbook (GRIF) / Krylova G., Sokolova. - M.: Master, 2009. 493p.

5. Henry Assael Consumer behaviour and marketing action. Front Cover. Kent Publishing Company, - Business \& Economics $1984-695 \mathrm{p}$.

Список використаних джерел:

1. Безрутченко Ю.В. Маркетинг в соціально-культурному обслуговуванні та туризмі [Текст] / Ю.В. Безрутченко. - М.: Дашков і К., 2010. - 231, [1] с.

2. Булганіна С.В., Томай Д.А. Використання методів маркетингових досліджень. У збірнику: Актуальні питання освіти і науки. Науково-практична конференція: у 11 частинах. 2014 р. 32-33.

3. Методи маркетингового дослідження в [Електронний ресурс] // URL: http://edu.dvgups.ru/METDOC/CGU/SOTS_KULT_ SERVIS/MET_N_ISL/METOD/U P/frame/4.htm (дата звернення: 21.04.2015).

4. Соколова М.І., Крилова Г.Д. Маркетинг: підручник (ГРІФ) / Крилова Г., Соколова. - М.: Майстер, 2009. 493с.

5. Henry Assael Споживча поведінка та маркетингові дії. Передня кришка. Видавництво Кента, Бізнес і економіка, 1984 $695 \mathrm{c}$.

\section{ФОРМУВАННЯ СИСТЕМИ УПРАВЛІННЯ ПІДПРИЕМСТВОМ ТУРИЗМУ НА ОСНОВІ ВИКОРИСТАННЯ ІННОВАЦІЙНИХ МАРКЕТИНГОВИХ ТЕХНОЛОГІЙ}

Анотація. Дана стаття присвячена формуванню системи управління туристичним підприємством на основі використання інноваційних маркетингових технологій. Розвиток і прийняття рішень в туристичному маркетингу супроводжується використанням методик, що враховують умови невизначеності в бізнесі і ступінь ризику. Останні можуть бути значно зменшені завдяки наявності надійної, достатньої, реальної та своєчасної інформації. Крім того, важливо пам'ятати, що будь-який хороший цифровий маркетинговий план базується на ряді добре побудованих профілів клієнтів, які окреслюють конкретні типи людей, яких туроператор хоче досягти через свої маркетингові кампанії. Незважаючи на те, що ви не повинні запускати нову маркетингову кампанію, поки не знайдете уявлення про демографічні показники, інтереси та діяльність веб-орієнтованого клієнта, ви також повинні постійно розвивати цей профіль на основі ваших останніх даних. Концепція маркетингу припускає, що інформація є не менш важливим ресурсом підприємства, ніж фінанси і персонал. зростання численних підприємств було зумовлене рекламою та маркетингом через традиційні шляхи - у тому числі газети, рекламні ролики, листівки та радіо. Вони створили чудеса для початкового зростання, але в цифрову епоху цей підхід потребує адаптації та розширення, щоб з'єднатися з сучасними споживачами. Таким чином, для успішного функціонування туристичного підприємства на всіх етапах його діяльності маркетингова інформація має першорядне значення. Пояснювальна інформація дає змогу сформулювати уявлення про фактори та причини зміни системи управління. Це робить, що планова інформація використовується у процесі розробки та прийняття рішень для цілей, стратегій та дій маркетингових програм. Метою статті є вивчення факторів впливу маркетингу на систему управління компанії, а також векторів, які можуть призвести до розробки адміністративної структури підприємства 3 використанням маркетингових технологій.

Ключові слова: інформація, управління, маркетингова стратегія, інформаційні комунікаційні технології, маркетингові технології. 